\title{
Research on Risk Management Strategy of Shipping
}

\section{Enterprise}

\author{
Qian Kun ${ }^{1}$ Duan Gui-jun ${ }^{2}$ and Peng-fei Zhang ${ }^{3}$ \\ 1. Wuhu Institute of Technology, Anhui 241006, China \\ 2. Qingdao Maritime Safety Administration, Shandong 266002, China \\ 3. Southampton Solent University, Southampton SO140RD, UK
}

\begin{abstract}
Risk management is to identify and assess risk in the process of shipping enterprise operation, then to make resolution to solve the risk, it is very important to the survival and development of shipping enterprises. In this paper, it analyzes the characteristics of shipping enterprise risk, and puts forward countermeasures and suggestions to improve the shipping enterprise risk management.
\end{abstract}

Key words: shipping enterprise, risk, shipping market, risk management.

\section{Introduction}

The shipping industry as a traditional industry, compared with other modes of transportation, has large capacity, low cost, low energy consumption, the advantages of the use of natural waters, plays an important role in the national economy. Due to the shipping demand is derived demand of international trade, however, the shipping is a high-risk industry, which is vulnerable to the influence of financial, political, international trade, such as the world economy change, The shipping has special risk from investment to buy a ship, putting into operation, loading the goods, maritime transport, in and out port, to deliver of the goods, With the acceleration of economic globalization, the market competition of the shipping enterprises facing is becoming more and more fierce, familiar with shipping risk management is vital to the survival and development of shipping enterprises, therefore, it has important practical significance to research on risk management of shipping.

Corresponding author: Peng-fei Zhang, Master Mariner, Ph.D. candidate, research field: shipping and maritime law. E-mail: shippinglaw@163.com.

\section{Risk Analysis of Shipping Companies}

Risk is normal to enterprise, the characteristics and source of risk are also different from different enterprise, Shipping demand is derived demand of international trade, there is a lot of passivity and dependency, the shipping market has a large volatility and uncertainty, and also has a serious consequences when accident happens, sometimes also face many unpredictable risk factors, the risk is very high. Many years of experience shows that the shipping market not only depends on the pattern of world trade, but also influenced by political change, economic shocks, natural disasters and other emergencies, the Asian financial crisis, the 911 event, the war in Iraq, the Somali pirates, and the recent international financial crisis. A shipping company takes enormous risks since its hire purchase shipping, to put into operation, to load the goods, in and out port, to deliver the goods, and a series of activities, especially the current of profound changes in the world economy, shipping companies will face the more and new risk.

\subsection{Risk of Ship Operation}

The modern shipping companies are global 
companies, operating routes across continents, the ship docks to ports around the world, these ports have great difference in geographic location, climate condition, or political, economic and legal system, so the shipping business is influenced by the international political, economic, trade provisions, world trade flows, trade protection, fuel prices, the natural conditions and other factors, also vulnerable to the factors of types of goods, quantity, distribution and so on, In addition, the port handling capacity, the workings of the ship and the relationship between national conditions also have direct relationship with shipping companies operating risk, Which may involve the risks of major area limits, between countries trade sanctions, shortage of goods, bad competition, customer churn, high oil prices and operating costs, retention, bad stowage, cargo damage, loss and other adverse operational risk.

\subsection{Risk of Ship Navigation}

The risks of shipping enterprises will increase because of long voyage, wide range of activities, changeable climate, serious environmental pollution and other factors, ship will suffer the irresistible natural disasters, such as wind, waves, tsunamis, heavy rains, thunder and lightning, ice, etc; accident such as stranding, sinking, collision, fire, explosion, missing may happen unexpected, the negligence or fault of some crew, professional technology level, ability and quality, ship management and other reasons will lead to the occurrence or expansion of transportation risk, will cause serious damage to the ship or cargo. At the same time, rampant piracy in Somalia and Malacca make shipping enterprises face more serious production safety situation.

\subsection{Risk of Shipping Market}

The shipping market is easily influenced by economy, politics and international relationship between supply and demand and other factors, it has the cyclical fluctuation, is easy to be affected by unexpected events, and sensitive to global events. Especially after the birth of FFA, the shipping market is more volatile, the large fluctuations and strong cycle of freight in shipping market will make the shipping enterprise's profit ability unstable and lead to higher earnings risk. The difference of market transparency, market intervention and degree of market competition can make the freight different, while profits and competitive ability of enterprises have a direct relationship with freight. The current world economic situation is not stable, the market has large periodic fluctuation problem. A vessel engaged in shipping can not be separated from the market and exist alone, also not be stored, it can not adjust the supply and demand of shipping market, Shipping companies often can only passively depend on ship operation ability, adapt to the changes of demand in shipping market, When demand changes in shipping market, shipping capacity can't always keep a certain balance with market demand because of time lag of shipping capacity adjustment, Because the shipping market instability always exist and freight rate fluctuation is inevitable, so the shipping enterprise cannot escape from the risk of market volatility, and maintain the stability of income.

\subsection{Risk of Currency and Interest Rate}

The shipping industry is a capital intensive industry which needs huge investment, has the characteristics of high risk, high investment, long cycle and low returns. Enterprises need a lot of money to expand and develop its own fleet, therefore, the entire shipping industry rely largely on the financial market, and is extremely sensitive to the change of currency and interest rate. After the outbreak of the financial crisis, governments have taken massive monetary and fiscal policy to stimulate economic growth, which make the currency and interest rate change sharply. With the world economy is moving into the post-crisis era, the currency and interest rate will vary substantially because of the trade protectionism, excess liquidity, 
withdraw stimulus policies and other factors. Due to the ship investment is to experience a long process, from the construction contract, started, water, putting into operation, to recover the investment. If the judgment of change trend of currency and interest rate is wrong, it will seriously affect the investment decision and leads to increasing risk of ship investment.

\subsection{Risk of Marine Environmental Pollution}

With the world's emphasis on marine environmental protection, the requirements for ship's environmental protection are getting higher and higher, the shipping company's investment in environmental protection is becoming bigger and bigger. Ship emissions, as well as containing waste, harmful material such as oils and toxin in the engine room bilge, chemical or tanker ship ballast water, washing water and ballast water can cause environmental pollution. Ship pollution insurance, in some areas, has been difficult to completely cover the amount of compensation, it can be said that a large range of pollution can lead to a company in bankruptcy. For example, in March 1989, "kerne Erickson-Valdez" oil tanker ran aground off the coast of prince William sound in Canada's west coast, about 36000 tons of crude oil leakage, the fees of cleaning costs and fines up to $\$ 8$ billion.

\section{Countermeasures and Suggestions to Improve the Risk Management of Shipping Enterprises}

3.1 Establishing Long-term Effective Mechanism of Risk Management to Improve the Level of Risk Management

The establishment of long-term mechanism for risk management of shipping enterprises, which make risk management become one part of the company management, to advance prevention, to make monitoring and evaluate later, through identification, estimation, evaluation and treatment of the shipping risk to prevent enterprise risk happens, or reduce the loss and influence to the lowest level, so as to protect the enterprise's survival and sustainable development ability of enterprises.

\subsection{Reasonable Control the Scale of Fleet, Strengthen Cooperation and Develop Diversified}

3.2.1 To Optimize the Fleet Structure and Reasonable Control the Scale of Fleet

Fleet is the main profitable tool of shipping company, as well as the core cost, is also the determinant of competitiveness. Keeping a good fleet structure is an important content of the shipping enterprise risk control, fleet structure including ship type, ship's tonnage, ship technical condition, ship age, shipping costs and other factors, the timing and reasonable fleet structure adjustment plays an important role to the shipping enterprise risk management. Because it is difficult to effectively relieve the pressure of the shipping industry supply exceeds demand in a relatively long period, for the healthy growth of the shipping industry, shipping enterprises should not build new ships to pursuit excessive scale growth, and be more use of leasing, purchase, joint venture to integrate the existing resources, to control the development speed in overall and focus on optimizing fleet structure.

3.2.2 To Strengthen Cooperation for Mutual Benefit and Win-win

Among the shipping companies, there not only exists competition, but also has the cooperation foundation. To strengthen the cooperation between the shipping companies can achieve scale benefit and complementary resource, reduce business risk and management cost, optimize route layout and jointly develop new markets. The world famous large shipping companies have cooperated with other companies in different forms. For example, in September 2014, China Ocean Shipping Company, France and the United Arab Shipping Company have signed an agreement on the trunk routes of ships, 
exchange of shipping space, space trading cooperation, etc. Therefore, due to profound changes in the world economy and in the shipping market today, the whole shipping cargo growth decline and continuing excess capacity, the shipping companies should strengthen the trade cooperation, to avoid vicious competition and achieve mutual benefit and win-win.

3.2.3 To Optimize the Industrial Structure and Develop Diversified Business

When the financial crisis happens, the shipping industry can be said to be one of the biggest impact of the industry. During the crisis, short industry chain will be detrimental to the stability, survival and development of enterprises. Shipping enterprises should strengthen the vertical integration according to their own conditions, and strengthen the joint and cooperation with industry chain upstream and downstream enterprises, actively extend the industry chain, to provide more extension services and value-added services to customers, it can not only avoid cyclical fluctuations, but also improve the service level, find new market opportunities and create greater value for customers.

\subsection{To Expand Channels and Reduce Shipping Market Risk}

3.3.1 By Using the COA (contract of carriage) Model and Other Tools to Make Periodic Development for Steady Development

Volatility is the main feature of the shipping market, with the periodic change of shipping enterprises, ups and downs, the radical retreat urgently, the shipping enterprises grow up with the shipping market, it is difficult to achieve scientific and steady development. Therefore, shipping companies should adopt positive and effective measures to minimize the influence of market fluctuation, Such as: by signing a long-term COA to stabilize supply of goods, slow rate volatility risk, adopt counter-cyclical operation to control investment cost, reduce the investment risk and so on. Therefore it can improve the ability of enterprises to withstand market risks, to make the enterprise in the market "cold" slower than others when cold, "hot" faster than others when hot, it make the enterprise follow passive to active control with the market change, and get a stable and sustainable development.

3.3.2 With Scientific Financial Derivatives to Avoid Shipping Market Risk

The changes of freight, oil price, currency and interest rate are external risk to shipping companies, it is very difficult for enterprises to adjust their business strategy for the implementation of effective risk control. Therefore, with the gradual recovery in the world economy, the financial market has become increasingly standardized, shipping companies do not have to give up eating for fear of choking, but try to use derivatives to achieve hedge risk, such as: avoiding freight fluctuation risk brought by FFA, using hedging tools to reduce oil cost risk of prices fluctuation, through the currency and interest rate swaps to control the ship investment risk. However, it must be emphasized that the shipping companies using financial derivatives should be based on risk control as the goal, and resolutely put an end to speculation, otherwise, it can not reduce the risk, but will increases the risk. To avoid speculation, it should be clear about the control targets, to hedge risk for the purpose, strictly control the size of transactions and exposures, through the formulation and implementation of operation procedures, to make non controllable factors as controllable factors, and get scientific and rational results.

\subsection{To Strengthen Safety Management and Ensure the Safety Operation of Ship}

The shipping companies should be strict with enforcement the safety management system, full implementation of safe production responsibility, play an effective role in safety management system, formulate and implement various prevention measures to ensure the safe operation of the ship. It should improve crew's safety awareness and sense of 
responsibility to ensure that the crew obey the rules of the ship navigation on duty, strengthen the education training to improve the emergency response ability and comprehensive quality of the crew, to realize the safety of navigation and marine environmental protection, improve the technical level of ship equipment to be strict in accordance with the control of ship emissions. According to the trend of high incidence Somali and India ocean pirates' attacks, the shipping companies should be fully aware of the serious situation of anti piracy, expand security range, increase the shore based support, through the formulation and the exercise of emergency preplan, to minimize impact of pirate attacks on business.

\section{Conclusion}

Risk management is very important to the survival and development of shipping enterprises, therefore, shipping companies should pay more attention to risk management, establish a long-term mechanism of risk management, to make systemic, dynamic and effective risk management, and formulate effective measures, to avoid and prevent risk by using the reasonable, legal method, to realize the sustainable development of shipping enterprises.

\section{References}

[1] Xie K.F. 2004. Enterprise Risk Management. Wuhan: Wuhan University of Science and Technology Press.

[2] Zhao G. 2004. Shipping Enterprise Management Beijing: People's Traffic Press.

[3] Zhang B.P. and Li P. 2006. "The International Shipping Market Risks and Avoid.” China Water Transport 4: 12-14.

[4] Shao R.Q.2005. "Ship International Shipping Investment Risk”. Water Transport Management 9: 1.

[5] Ceng Z.S. 1999. "International Shipping Companies Operating in the Shipping Risk." Water Transport Management 4: 25-28.

[6] Qian Z.R. 1999. "Shipping Companies How to Resolve the Business Risks.” China Water Transport 9.

[7] Wang K. 2009. "Shipping Enterprise Comprehensive Risk Management Framework Research.” Ph.D. thesis, Dalian Maritime University.

[8] Zhang Y.M. and Qian S. 2014. "Shipping Enterprise's market Risk Management Strategy Research.” Journal of World Shipping 11. 